\title{
Trends and Tips in Protein Engineering, A Review
}

\author{
Kian Mau Goh ${ }^{a *}$, Goh Poh Hong ${ }^{a}$, Ng Han Chyi @ Pearly Ng ${ }^{a, b}$, Chai Kian Piaw ${ }^{a}$, Raja Noor Zaliha Raja Abdul Rahman ${ }^{c}$ \\ ${ }^{a}$ Faculty of Biosciences and Bioengineering, 81310 Skudai, Universiti Teknologi Malaysia. \\ ${ }^{b}$ Sunway College, 81100 Johor Bahru, Malaysia. \\ ${ }^{c}$ Enzyme and Microbial Technology Research, Faculty of Biotechnology and Biomolecular Science, 43400 Serdang, Universiti Putra Malaysia
}

*Corresponding author: gohkianmau@utm.my

\section{Article history}

Received :1 August 2012

Received in revised form :7 Sept.

2012

Accepted :1 October 2012

Graphical abstract

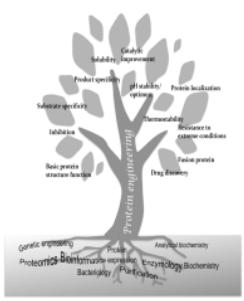

\section{Abstract}

Protein engineering is widespread approach in the branch of protein science. It is a useful tool for elucidating function of a single or a stretch of amino acids. Some protein engineers use it to improve the properties of a protein. Despite protein engineering is a powerful tool; it remains an unexplored field in Southeast Asia, specifically in the developing countries. Therefore, this chapter aims to provide a basic overview on the tips, methods, applications, common problems and solutions, as well as the progress of protein engineering in Southeast Asia.

Keywords: Protein mutagenesis; protein modification; site-directed mutagenesis; random mutagenesis

\begin{abstract}
Kejuruteraan protein adalah salah satu cabang protein sains yang digunakan secara meluas. Ia berkesan bagi menentukan fungsi satu atau lebih asid amino. Sesetengah jurutera protein menggunakan kejuruteraan protein untuk menambahbaik ciri-ciri protein tertentu. Walaupun kejuruteraan protein telah terbukti berkesan, ia tetap kurang member gambaran mengenai tip, kaedah, aplikasi, penyelesaian terhadap masalah-masalah yang sering berlaku serta perkembangan terhadap kejuruteraan protein di Asia Tenggara.
\end{abstract}

Kata kunci: Kejuruteraan protein; pengubahan protein; protein mutasi

\subsection{INTRODUCTION}

Protein can be found in abundance in all living organisms in the form of enzyme, membrane receptor, antibody, or cytoskeletal structure. It is a biological polymer that comprises 20 amino acids arranged in specific sequence, which is then joined together by peptide bonds. Intermolecular interactions such as disulphidebridges, electrostatic interactions, salt-bridges, hydrogen bonds and Van der Waals interactions occur between adjacent amino acid residues. Based on the known coding genes discussed in the Next-Generation Sequencing projects, more than 100,000 human proteins were discovered [1]. In addition to that, it is known that at least 25,000 types of enzymes exist in nature. Although most proteins are different, they share common amino acids builds. However, given the vast number of protein types, the number of basic topological motifs in protein structures is probably limited to around 1000 . This implies that similar folding may be observed in different proteins with distinct functions.

Enzymes that are of different domains or kingdoms may still exhibit the same catalytic function but differ in certain properties, such as thermo-stability, activity speed, substrate specificity and others. Such variation in the properties mentioned is also observed in two species-related proteins. However, the catalytic residues are almost always well-conserved in enzymes that have similar function but different organism source.

However, the enzymes share very few similarities when their full-length protein sequences are compared. For example, alphaamylase is a very common enzyme with a length of about 500-600 amino acid residues. The catalytic sites on alphaamylase are well-conserved among family members. Yet, they share only $10 \%$ similarities in their whole protein sequence. The variations in amino acids arrangement affect the structural folding and packing of polypeptides, and thus, the properties and behaviours of the functional proteins. Therefore, a change in a single amino acid in a polypeptide sequence is enough to affect the properties of a protein, and to determine its lethality. In humans and animals, mutation in the gene has resulted in the formation of prion protein due to the misfolding of polypeptide [2]. On the other hand, modification of certain residues in Bacillus licheniformis amylase had produced several novel thermo-stable amylases [3] that are very important in the starch industries.

Protein engineering involves manipulation of protein sequences at the molecular level to alter the protein functions. For that reason, it is also commonly known as protein modification, protein tailoring, or protein mutation. A competent protein engineer should have vast knowledge in the field of genetic 
engineering, biochemistry, enzymology, protein expression and purification, bacteriology, proteomics, bioinformatics, and other relevant laboratory skills. Figure 1 shows the various fields of biotechnology and desired protein characteristics that overlap with each other, and which serve as a platform for protein engineering.

\subsection{Applications of Protein Engineering}

Protein engineering enables the identification of functional amino acids in a particular protein and subsequently, the improvement of the protein properties. Over the past few years, protein engineering has successfully improved various protein properties, especially high demand industrial biocatalysts such as lipase, esterase, amylase, protease, xylanase, cellulase, and etc. Table 1 shows the different application areas of protein engineering as well as the protein sources, research goals and outcomes.

An ideal industrial enzyme must be able to withstand harsh conditions such as extreme $\mathrm{pH}$, temperature and salinity. Unfortunately, most of the existing enzymes are sourced from mesophilic organisms and they are only able to function in a moderate reaction conditions. Hence, protein engineering is carried out to enhance the performance of current industrial enzymes to reduce the processing cost and time in the relevant industry. Accordingly, enzyme properties such as $\mathrm{pH}$ tolerance, thermal stability, specific activity, inhibitor tolerance, substrate specificity, and solubility become of interest when engineering an industrial biocatalyst (Figure 1).

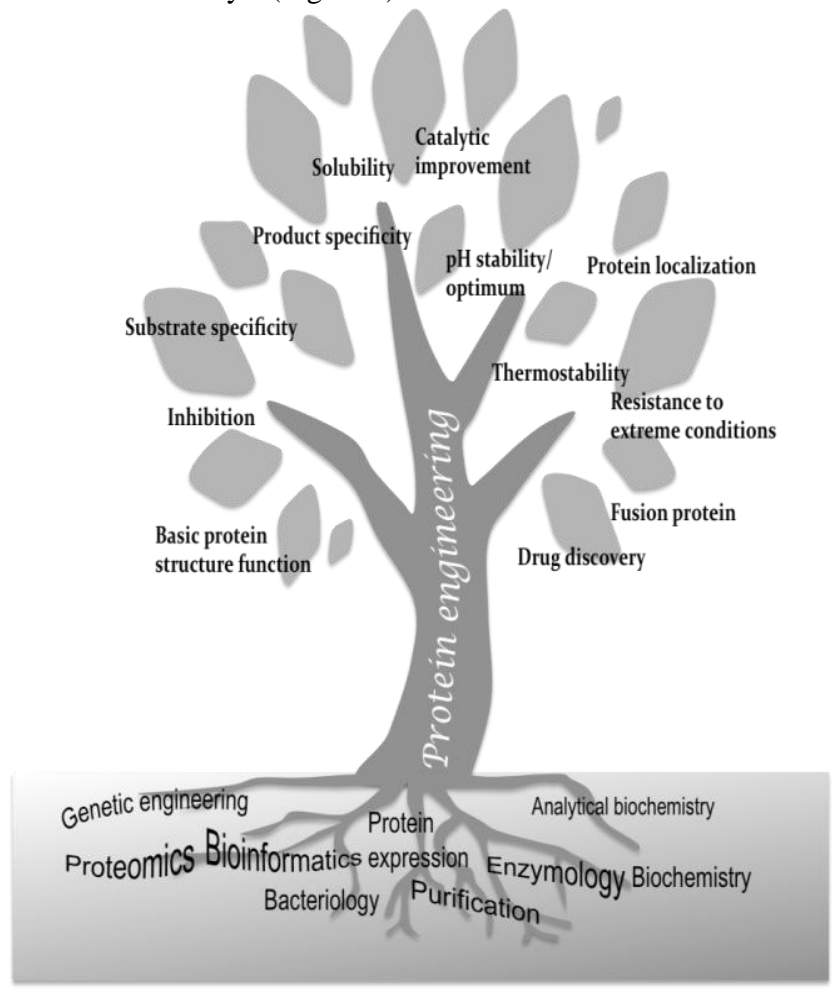

Figure 1 Relationship between protein engineering and other properties of biotechnology

On top of that, protein engineering contributes greatly to the field of medical research, particularly in de novo drug discovery and drug improvement. For instance, protein engineering helped created amylase-inhibitor (commonly known as starch blocker) that helps to solve obesity. Obesity is related to excess sugar intake through the daily uptake of starch-rich food, such as potato or rice. Upon consumption, these starchy foods are converted into oligosaccharides (sugars) by amylase, leading to an increase in sugar intake. However, several years ago, a protein engineer developed an amylase-inhibitor that blocks the degradation of starch and thus, providing a solution to obesity that is related to excessive sugar intake [4].

Table 1 Applications of protein engineering in different areas

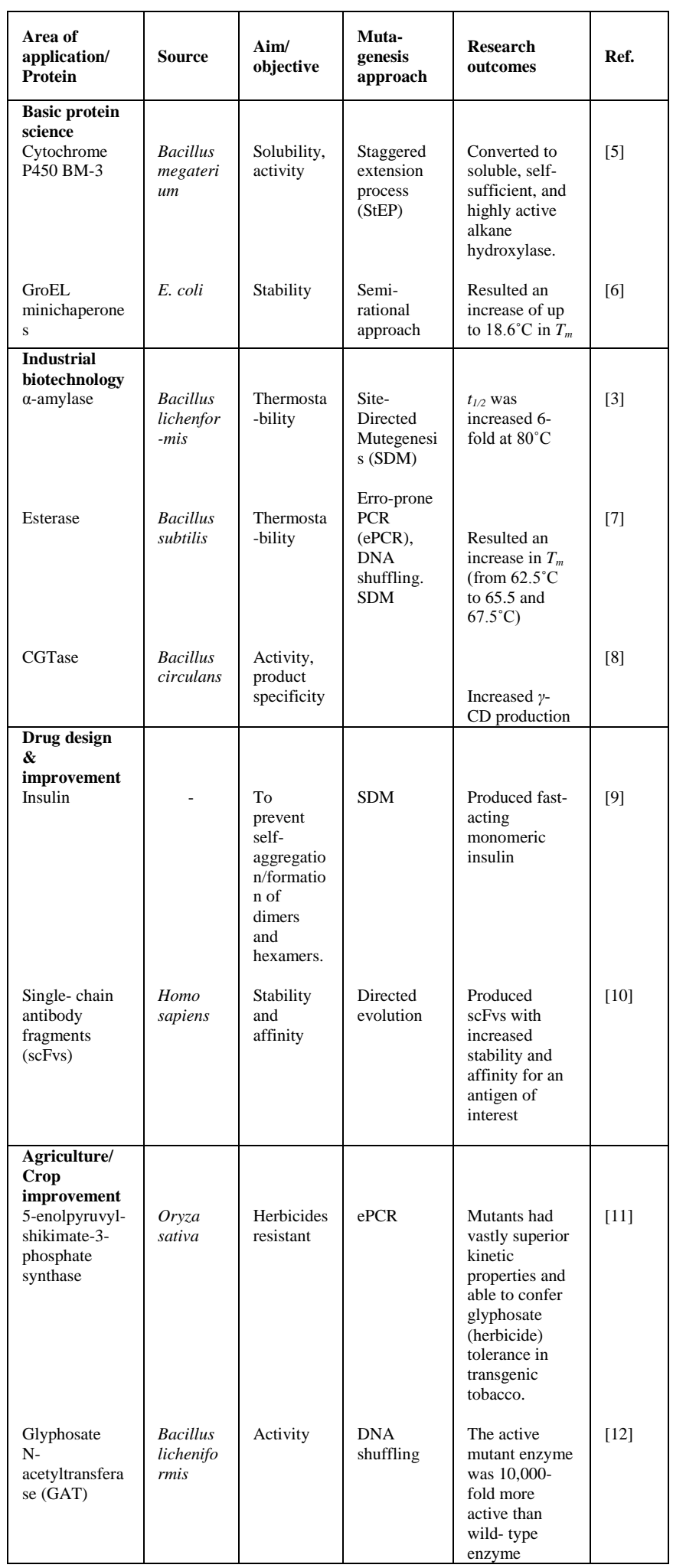




\subsection{APPROACHES IN PROTEIN ENGINEERING}

There are two general approaches in protein engineering chemical modification and gene manipulation. The chemical mutation approach involves the addition of mutagenic chemicals, leading to the modification of amino acid or intermolecular bonding. An example is the oxidation of disulphide bonds by $\square$ mercaptoethanol, causing a permanent loss of disulphide bonds within a protein. This example is commonly carried out in the hairstyling industry. By applying $\square$-mercaptoethanol (a common hairstyling product) onto hair, the hairstylist is able to achieve a hair-straightening effect due to the oxidation of disulphide bonds within the keratin. By definition, the hairstylist is a protein engineer too!

The chemical approach is relatively easy and straightforward, as it does not require information of the gene or protein sequence or the three-dimensional protein structure. However, despite these advantages, the chemical modification approach has several drawbacks. It requires repetition from batch to batch and usually causes non-specific mutation. It is also inadequate to generate deletion or insertion into a specific region of a protein. Therefore, in this report, the chemical modification approach will not be discussed. Instead, more attention will be focused on discussing protein modification using the molecular approach.

\subsection{Site-Directed Mutagenesis (SDM)}

DNA modification can be done using the Kunkel method [13], site-directed mutagenesis, directed evolution or by simply using the commercial kits. These approaches are complementary to each other and have their own strengths and limitations.

The site-directed mutagenesis (SDM) approach is also known as the rational design. For simplicity, we shall define the SDM as any technique that changes a specific residue or a stretch of residues at a defined position in a protein sequence, either through substitution, deletion, or insertion. The first step for beginning protein engineers is to ask three very practical questions:

1. Which amino acid should be mutated in the protein sequence?

2. What (type of) amino acid should replace the mutated amino acid in the sequence?

3. What is the rationale behind this residue replacement in the sequence?

The selection of amino acid to be mutated is tedious and the outcome is hard to predict, even for experienced protein engineers. In order to increase the success rate, precise information on the structure of the target protein is needed, as well as a good understanding and knowledge in the basic function, substrate binding, and catalytic mechanism of the protein of interest.

The second step for SDM involves retrieving information of protein alignment. A feasible mutation design is directly dependent on how the comparison is made during the analysis of protein alignment. Vast information, clues, and deduction of function for certain amino acids can be retrieved from the alignment. Assuming that you have an unknown protein sequence, denoted as Protein-X, it is possible to align the sequence with other known protein sequences using bioinformatics software. The selected references should have well-characterized information such as known protein crystal structure, simulation data or some form of mutagenesis work performed before.

Figure 2 shows the mutation selection on a residue in Protein-X by comparing it with other reference sequences. In
Protein-X, Asparagine (Asn, N) is found at position 12. Of the 20 amino acids, Asn (N), Glutamine (Gln, Q), Methionine (Met, M) and Cysteine (Cys, C) can be classified as thermolabile, due to their tendency to undergo deamidation of oxidation at high temperature. On the other hand, Arginine (Arg, R) is observed in Protein-P and Protein-Q, which are similar proteins from other sources. In this example, assuming from an experimental data, Arginine at position 12 in Protein-P plays a role in stabilizing the protein conformation. Due to a large side chain, Arg may be useful in short or long range ionic interactions that stabilize the protein folding. Therefore, substituting Asparagine with Arginine (written as N12R, or 12Asn $\rightarrow$ Arg) will improve the thermostability of Protein-X, which is a desirable property for industrial uses. This imitation approach, also known as rational design is the most helpful step for new beginners in this field.

Using the polymerase chain reaction (PCR) technique, precise mutation can be introduced to the target gene with the use of mismatched primers, which are partially complementary to the template DNA. Use of mismatched primers serves as the fundamental basis for all PCR mutation approaches. Thus, the length of PCR primers must be sufficiently long to allow unique binding to the desired locations on the template. The SDM-PCR approach is not just limited to generating terminal sequence mutations, but also for creating internal sequence mutations in both linear and circular DNAs. Most of the linear DNA SDMPCR procedures are relatively simple and have high mutational efficiencies. For this reason, only linear DNA SDM-PCR approaches will be discussed in this report.

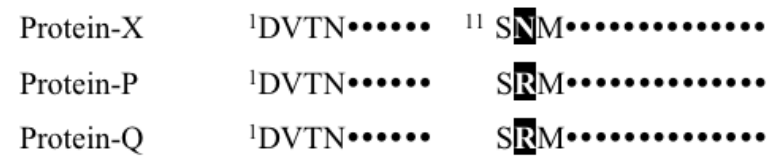

Figure 2 Example of selecting a residue to mutate in rational design (The dots can be any amino acid)

Utilization of a proofreading DNA polymerase is also essential in SDM. Proofreading in this context refers to the ability of the polymerase to carry out $3^{\prime}$ to $5^{\prime}$ exonuclease activity to avoid any undesired mutation during the DNA amplification. The $P f u$ and Vent were formerly the preferred proofreading DNA polymerases. However, the amplification speed for Pfu DNA polymerase is half that of normal Taq polymerase. This results in lower efficiency in generating high quantity of amplicon.

In SDM, primers are designed to be longer (> $35 \mathrm{bp}$ ) than the common primer length (approximately $21 \mathrm{bp}$ ) as shorter primers are more easily digested by the proofreading polymerase, causing failure in PCR amplification. This has been a common problem in protein engineering study in the past. With the discovery of $K O D$ DNA polymerase (Novagen) and Phusion DNA polymerase (Finnzyme), SDM-PCR can be done at a faster rate to generate higher yield. Nonetheless, $K O D$ polymerase and the commercial kit are quite costly and Phusion polymerase seems to be a better alternative for the abovementioned reasons.

\subsubsection{Megaprimer-PCR}

Kammann et al. first came up with the megaprimer-PCR approach in 1989 [14]. It is a simpler and more cost-effective method than the traditional Kunkel method. The mutational efficiency of this megaprimer-PCR approach can be as high as $100 \%$ but the length of the megaprimer generated from the first run of PCR should not exceed 600 base pairs. Any length exceeding this figure will reduce the efficiency of complete gene amplification in the second 
run of the PCR. The conventional megaprimer-PCR approach involves two rounds of PCR using three primers, which include two flanking primers and one mutagenic internal primer (Figure 3).

In the first run, a forward primer and a mutagenized reverse primer are used to amplify a portion of the gene of interest. The amplicon, which is now the mutation-containing megaprimer, is then gel-purified to eliminate any other primers left from the PCR run. The purified megaprimers and external reverse primers are then subjected to a second run of PCR to obtain a complete mutated gene sequence (Figure 3).

The conventional megaprimer-PCR approach is very effective, but laborious and time-consuming compared to the revised megaprimer-PCR method. In the revised method, a complete mutated gene can be synthesized in a single tube by using a pair of forward and reverse flanking primers with significantly different melting temperature $\left(\mathrm{T}_{\mathrm{m}}\right)$ [15]. To generate the megaprimer in the first run, the annealing temperature of the primers is set to be around $42-46{ }^{\circ} \mathrm{C}$. After a numbers of complete cycles of PCR, the PCR machine is reset without withdrawing the reaction tube. In the second run, a higher annealing temperature (approximately $70-72^{\circ} \mathrm{C}$ ) is set. An elevated annealing temperature prevents the synthesis of the megaprimer. Finally, a complete mutated amplicon is generated in a single tube.

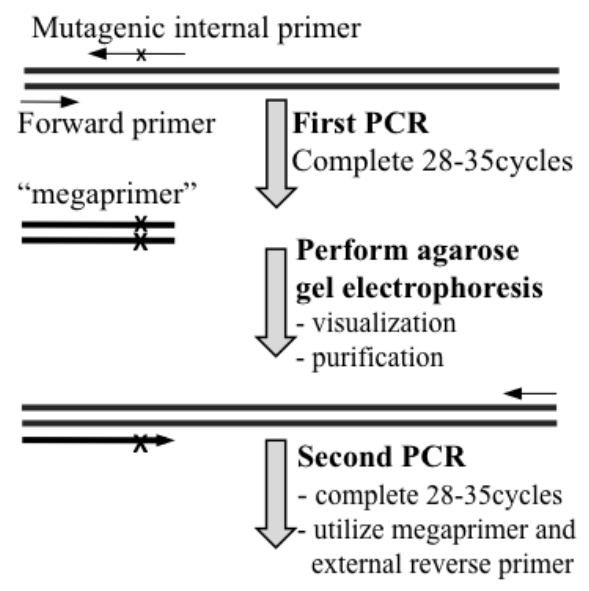

\footnotetext{
Full-length mutagenic gene with desired single point mutation.

-Proceed with purification, ends

digestion, ligation and transformation.
}

Figure 3 Conventional megaprimer PCR

\subsubsection{Overlapping-Extension PCR}

Although the megaprimer-PCR approach is a very useful method with moderate cost and requires relatively less runtime, it has several limitations as well, outlined in Table 2. The overlappingextension PCR (OE-PCR) on the other hand, is an excellent alternative to standard SDM method. OE-PCR can create single point mutation, multiple point mutations at distantly located position, residues insertion or deletion, and fusion fragment mutagenesis, which are not attainable in the megaprimer-PCR approach.

Basically, OE-PCR is carried out in three sequential PCRs, requiring a total of four primers. The first run of PCR generates the first half of the gene of interest while the second run of PCR generates the other half, of which both PCRs are done separately.
Next, the respective amplicons are gel-purified to remove templates and primers left from the PCRs. The purified DNA fragments are then joined together in the third run of PCR with the use of two external primers (Figure 4).

Table 2 Comparison of basic megaprimer-PCR and overlapping extension-PCR

\begin{tabular}{|c|c|c|}
\hline Criteria & Megaprimer-PCR & $\begin{array}{l}\text { Overlapping } \\
\text { extension-PCR }\end{array}$ \\
\hline Number of primers & 3 & At least 4 \\
\hline $\begin{array}{l}\text { Number of PCR } \\
\text { round }\end{array}$ & 2 & At least 3 \\
\hline Cost & Lesser & More \\
\hline Time required & $\begin{array}{l}\text { Lesser } \\
\text { - Generated }\end{array}$ & More \\
\hline $\begin{array}{l}\text { Restriction/ } \\
\text { limitation }\end{array}$ & $\begin{array}{l}\text { should be } \leq \\
600 \mathrm{bp} \\
\text { " Difficult to do } \\
\text { multiple points } \\
\text { mutation }\end{array}$ & $\begin{array}{l}\text { Require slightly } \\
\text { more time and } \\
\text { effort }\end{array}$ \\
\hline Advantages & $\begin{array}{l}\text { " Relatively } \\
\text { simpler }\end{array}$ & $\begin{array}{l}\text { " Insertion, } \\
\text { deletion and } \\
\text { fusion protein is } \\
\text { possible } \\
\text { " Multiple points } \\
\text { mutagenesis is } \\
\text { easy }\end{array}$ \\
\hline
\end{tabular}

The principle of OE-PCR is rather simple; the complementary internal reverse primer (in the $1^{\text {st }} \mathrm{PCR}$ ) and internal forward oligomer (in the $2^{\text {nd }} \mathrm{PCR}$ ), share an overlapping region. However, special care should be taken when designing the primers. As reported by McPherson and Moller [16], the optimum length of an overlapped region should be kept between 10-15 base pairs. The intended mismatches should be situated around the middle region of the primers, or located toward the $5^{\prime}$ ends. Mismatches should not lie too close to the $3^{\prime}$ end of primers as this may result in low or no PCR yields. In addition, the overall length of mutagenic primers should be between 20 to 40 nucleotides and the length of the primer is directly proportional to the number of mismatches being introduced. Not more than six adjacent nucleotides is to be substituted in the mutagenic primer and the substituted nucleotides stretch should be positioned 3 nucleotides downstream from the $5^{\prime}$ end of the primer [17]. 


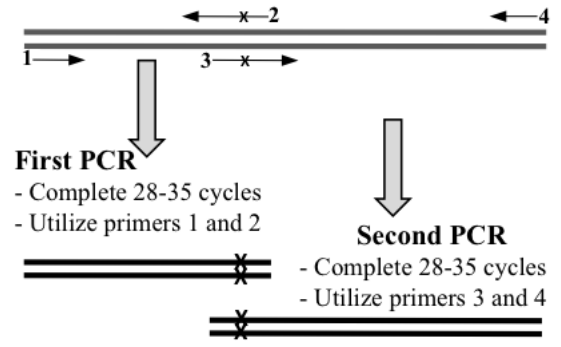

Gel purification of the for each PCR products

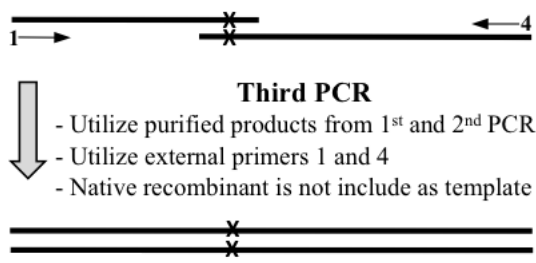

Full-length mutagenic gene with desired single point mutation.

-Proceed with purification, ends

digestion, ligation and transformation.

Figure 4 Overlapping extension PCR for single codon or amino acid substitution

\subsubsection{Overlapping-Extension PCR with Modifications}

Protein secondary structure can be categorized as $\square$-helices, $\square$ sheets or loops. Some loops are relatively more flexible and can cause structural destabilization for certain proteins. Loop shortening or deletion at the desired position may sometimes lead to the increase of protein thermostability [18]. Loop deletion has been reported to affect enzyme catalytic function and product specificity [19-20] while the deletion of a stretch of amino acids in the $\square$-helices and $\square$-sheets is also reported to affect stability [21].

Figure 5A shows a stretch of residues that is intended for removal. Primer 1 and 2 are used to amplify the first fragment, while Primer 3 and 4 are used to produce the other fragment. The 5 ' end of Primer 2 is designed to contain overlapped sequences with Primer 3. The two fragments are then assembled together in the final PCR.

A similar approach can be used for insertion of a short sequence of nucleotides. Extra nucleotides are added into the two internal primers and after two cycles of amplifications, the ends of the amplicons will consist of the overlapped regions (Figure 5B). Another interesting application of OE-PCR is to create fusion protein. Examples of such application are reported earlier [22].

OE-PCR can also be modified to achieve domain swap between two homologous proteins as illustrated in Figure 6. Gene 1, which was extracted from a mesophilic encodes for a thermolabile protein, while gene 2, extracted from a thermophile, encodes for the thermostable counterpart protein. The middle region or domain is responsible for the thermostability of the protein. Domain B' (coded by part of gene 2) can be used to replace Domain B (coded by part of gene 1) using the modified OE-PCR shown in Figure 6. Both primer 2 and 3 consist of a few nucleotides complementary to a region in gene 2 that codes for the terminal ends of Domain B'. As a result, an overlapped region is created among these three fragments, enabling domain substitution to occur.

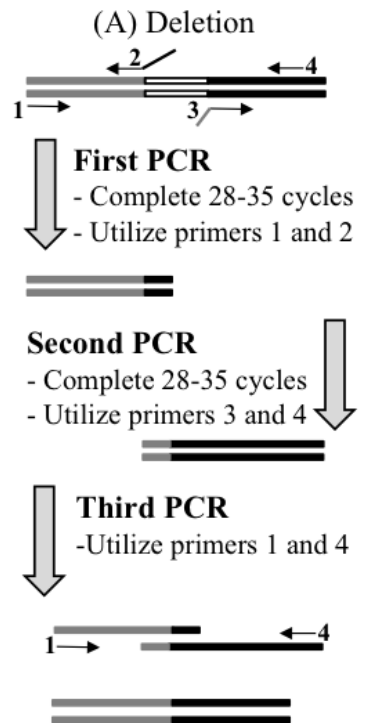

Full-length mutagenic gene with desired deletion.

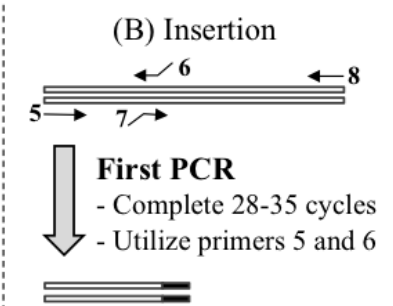

Second PCR

- Complete 28-35 cycles

- Utilize primers 7 and 8

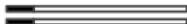

Third PCR

- Utilize primers 5 and 8

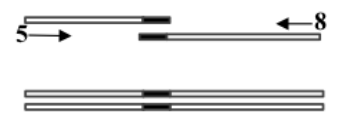

Full-length mutagenic gene with desired short insertion.

Figure 5 (A) Deletion mutagenesis (B) Insertion mutagenesis
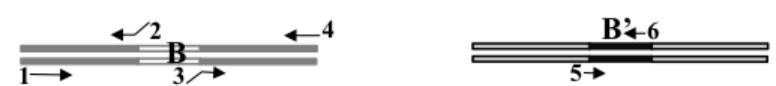

First PCR

- Utilize primers 1 and 2
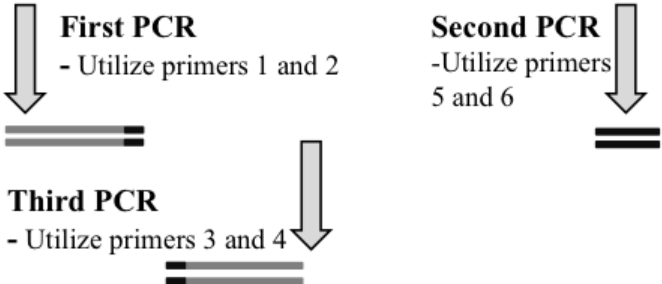

\section{Combining products of $1^{\text {st }}$ and $2^{\text {nd }}$ PCR in Forth PCR}

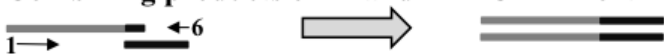

Combining products of $4^{\text {th }}$ and $3^{\text {rd }}$ in Fifth PCR

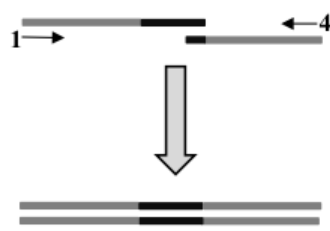

Full-length mutagenic gene with desired replacement of fragment

Figure 6 Domain swapping with OE-PCR

\subsection{Directed Evolution}

A good rational design requires certain level of understanding on the primary, secondary and tertiary protein structures. In contrast to rational design, directed evolution does not require extensive information and geometry location of each residue within the 3D structure. In this approach, a mutagenized gene library is constructed using techniques like DNA shuffling, error-prone PCR, and staggered extension process (StEP).

Directed evolution has a relatively low efficiency rate and a low concentration of final PCR yield is often a limitation factor to 
downstream processing. ExoSAP-IT PCR Product Cleanup (Affymetrix) may provide a solution to this problem and serves as an alternative to conventional column or beads-based PCR purification kits. Although the manufacturer declares that product loss from the DNA purification step is negligible, one should verify the claim by experiment.

Directed evolution also poses another challenge in terms of screening and selecting the huge number of potential mutants. Depending on the objective of study, a mutant library may range from a few hundred to thousands of colonies. Thus, high throughput screening (HTS) may be useful in identifying positive clones from the huge mutant library since it is known to be a sensitive and efficient screening method. In most laboratories, HTS assays are carried out on a microtiter (96 deep-wells) plate, while in a more sophisticated laboratory or where very large samples are involved; robotic liquid handling system may be used. An example of such a system is Eppendorf EpMotion.

\subsubsection{Error Prone PCR}

Error prone PCR (ePCR) is the easiest mutagenesis method to perform in the laboratory. Several commercial kits are available, such as GeneMorph II Random Mutagenesis ${ }^{\circledR}$ Kit which uses the Mutazyme II DNA polymerase (Stratagene) and a Diversify PCR Random Mutagenesis ${ }^{\circledR}$ Kit (Clonetech).

ePCR increases the probability of error occurrence during DNA amplification (Figure 7). The errors are intentionally introduced by adjusting one or more parameters in the PCR. Use of nonproofreading DNA polymerase such as native Taq polymerase, high concentrations of magnesium ions and/or manganese ions, biased amount of dNTPs, and/or increase of amplification cycles are the parameters commonly employed in ePCR.

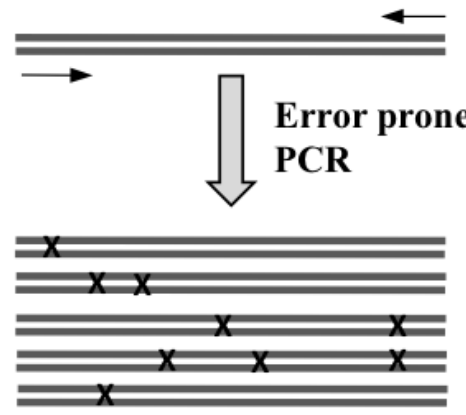

Figure 7 Random mutagenesis error-prone PCR

\subsubsection{DNA Shuffling}

DNA shuffling is a powerful directed evolution technique. This approach has improved catalytic properties of various industrial enzymes such as glucose dehydrogenase [23] and $\beta$ - 1,3- 1,4glucanase [7] and many more. The idea of this method is to create a library that consists of a variety of chimeras resulting from the joining of various homologous genes using the self-priming PCR technique. The homologous parent genes must share more than $80 \%$ similarities [24]. DNA shuffling comprises five basic steps, as shown in Figure 8, which are:

(i) Isolation of parent genes,

(ii) Random fragmentation of parent genes using DNase I,

(iii) Collection of DNA fragments with specific molecular size, (iv) Reassembly of these DNA fragments using selfpriming PCR, and lastly

(v) Conventional PCR to generate full-length chimera genes
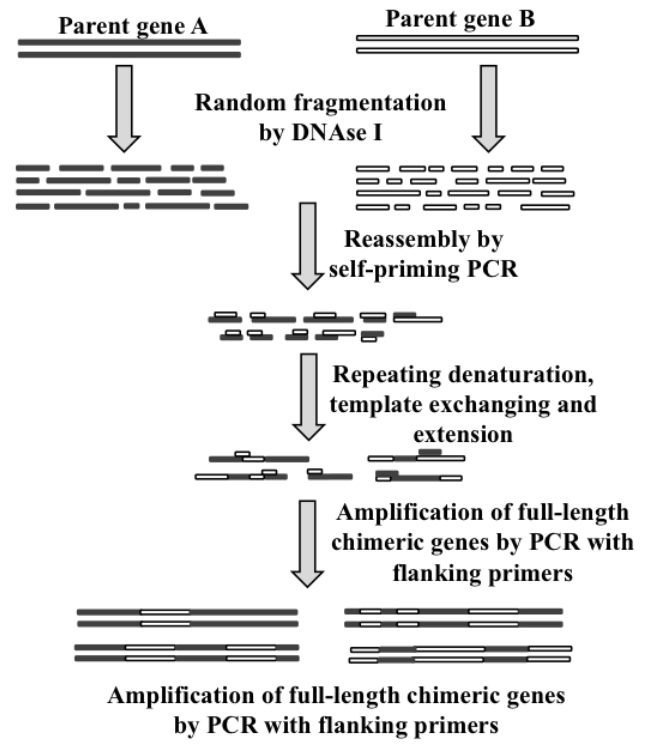

Figure 8 Random mutagenesis by DNA shuffling

\subsubsection{Staggered Extension Process}

Staggered extension process (StEP) is another popular and homology-dependent method for in vitro DNA recombination. The sequence identity among the parental genes should be more than $85 \%$ for efficient recombination [25]. The full-length parent genes are used as templates to synthesize chimera progeny genes in a single tube PCR reaction with very short duration of annealing or extension steps.

StEP involves priming the templates and repeating the denaturation cycles, which is then followed by extremely short cycles of annealing or extension processes. In each cycle, the growing fragments are allowed to anneal to different complementary templates to produce various chimera gene fragments. The reaction is stopped when full-length genes are formed. Increases in template switches will lead to a high crossover frequency.

The type of DNA polymerase used in StEP is critical and it may also affect the crossover frequency. High-fidelity DNA polymerases such as $P f u$ and Vent DNA polymerase are able to create high crossover frequency since more template switches are required until the full-length genes are formed [24]. Nevertheless, the number of PCR cycles needed is greater as compared to methods that use $K O D$ and Taq DNA polymerase, which are known to have fast extension rate.

\subsection{PROTEIN ENGINEERING AS EASY AS ABC}

The earlier sections explained the methods and some applications of protein mutation. A question one may ask is "How should I start?". This section provides a comprehensive guideline for the beginners.

First of all, identify your protein of interest. Then, clone the gene that encodes your protein of interest into a vector. The vector should be able to express the gene with minimum or no inclusion body and the recombinant protein produced can be purified. In 
certain applications, purification may be optional. It is not the intention of the authors to explain in detail gene cloning but useful information on this aspect may be found in many textbooks.

Prior to the protein mutation lab work, it is necessary to analyse the gene and amino acid sequence of your protein. The analysis is particularly essential when rational design is the chosen method and is a guidance to solving the three fundamental questions mentioned earlier. Figure 10 shows a series of DNA and protein analyses. The common gene analysis may involve determination of an open reading frame and restriction sites within the gene. Lastly a DNA-protein translation is performed to obtain the amino acid sequence.

From the amino acid sequence (primary structure), important information can be predicted such as the protein molecular mass, pI, amino acid compositions, hydrophobicity, solubility, stability, extinction coefficient, cellular localization, flexibility and other relevant details. The ExPASy ProtParam tool is a good and popular online tool for protein chemical and physical properties determination. Other more useful online programs for academics can be found in Table 3. The NCBI Blast search is an important software to determine the similarity between target protein and other public sequences. It provides general information such as sequence alignment and protein tree distance analysis. The alignment serves as a platform to determine the conserved regions and important amino acids and thus, assisting us to decide which residue(s) to mutate.

After analysing the primary structure, prediction of protein secondary structure can be easily done using lists of software as suggested in Table 3. Secondary structure prediction may be less useful as the accuracy and consistency of such prediction programs still require detailed validation. In contrast, tertiary structure offers more practical information and thus, generating a deeper and better understanding of the target protein.

Generally, soluble protein structure can be determined using X-ray crystallography and nuclear magnetic resonance (NMR). Higher resolution of protein structures can be obtained using the $\mathrm{X}$-ray crystallography method and synchrotron radiation, with the latter being a superior method. X-ray structures will certainly ease the work of most protein engineers but unfortunately, a good crystal structure is hard to obtain in the laboratories due to difficulties in producing sufficient amount of highly purified protein. The high purification cost involved is also a problem.

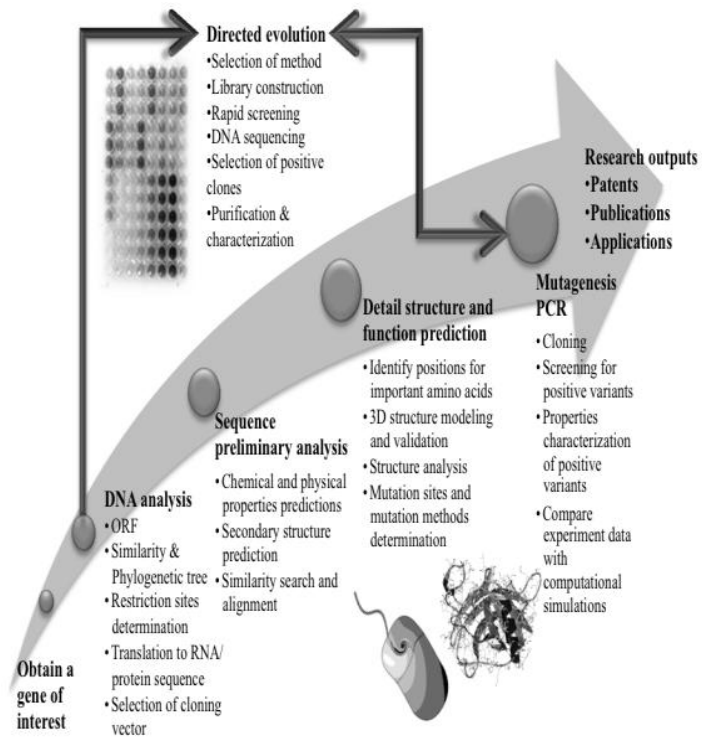

Figure 9 A schematic process for redesigning a selected protein
In-silico protein modelling serves as a good alternative to predict the theoretical structure of a protein. It is rapid and cost-effective. The Modeller program (currently under the commercial license of Acceryls) created by the Sali laboratory [26] is considered as one of the best predictors. Many open source protein structure homology-modelling servers such as SWISS-MODEL, CPHmodels and ROSETTA are available online. However, researchers may want to verify the quality of the models generated using these servers as errors in the backbone or side chains of amino acids are frequently discovered. Table 3 shows a list of some validation software available. The errors occur largely due to incorrect or unsuitable choice of template(s), nonavailability of template(s) and misalignment caused by the presence of long gaps in the protein sequence. Although homology-modelling functions are a useful tool for protein engineers, it is important to bear in mind the concept of "rubbish in, rubbish out". If the predicted structure is mostly inaccurate, rational design will not generate a good mutant with enhanced properties.

Recently, a free software that is both accurate and has powerful predictive capability has attracted much attention from and discussion among the protein engineers. The I-TASSER, developed by Zhang [27], is able to predict accurate protein models even if it is a novel protein sequence without a suitable template. In conventional modelling program, the templates selected for building the model should carry at least $40-60 \%$ similarities. Interestingly, even with as low as only $15-30 \%$ template similarity to target protein sequence, a fairly good preliminary structure can be generated with I-TASSER. Other prediction software programs were unable to generate a similarly convincing result (author's unpublished work). Besides structure modelling, I-TASSER provides a directory of binding site predictions based on analogue structures found in the Protein Database (PDB). This feature is extremely valuable in deciding which residues to mutate in a protein sequence.

While there are many free programs available online (refer Table 3), there are also some other offline applications that can be downloaded for the same purpose (refer Table 4). The programs listed in the tables are very useful for the analysis of gene, design of primers, retrieval of protein primary sequence, prediction of protein secondary structure, modelling and validation of protein $3 \mathrm{D}$ structure and investigation of function and properties of protein from 3D structure.

Table 3 List of online tools for DNA and protein analysis

\begin{tabular}{|c|c|}
\hline $\begin{array}{l}\text { Online Software/ } \\
\text { Program }\end{array}$ & Website Address \\
\hline \multicolumn{2}{|c|}{ 1. DNA to Protein Translation } \\
\hline $\begin{array}{l}\text { ExPASy Translate } \\
\text { tool }\end{array}$ & http://expasy.org/tools/dna.html \\
\hline EMBOSS Transeq & http://www.ebi.ac.uk/Tools/emboss/transeq/ \\
\hline \multicolumn{2}{|c|}{ 2. Open Reading Frame Searches } \\
\hline NCBI ORF Finder & http://www.ncbi.nlm.nih.gov/gorf/gorf.html \\
\hline OrfPredictor & $\begin{array}{l}\text { http://proteomics.ysu.edu/tools/OrfPredictor. } \\
\text { html }\end{array}$ \\
\hline $\begin{array}{l}\text { ORF Finder (Gene } \\
\text { Infinity) }\end{array}$ & $\begin{array}{l}\text { http://www.geneinfinity.org/sms/sms orffin } \\
\text { der.html }\end{array}$ \\
\hline \multicolumn{2}{|c|}{ 3. Restriction Endonuclease Sites } \\
\hline Webcutter 2.0 & http://rna.lundberg.gu.se/cutter2/ \\
\hline NEBcutter 2.0 & http://tools.neb.com/NEBcutter2/index.php \\
\hline WatCut & $\begin{array}{l}\text { http://watcut.uwaterloo.ca/watcut/watcut/tem } \\
\text { plate.php }\end{array}$ \\
\hline \multicolumn{2}{|c|}{ 4. PCR Primer Design } \\
\hline Primer3 & $\begin{array}{l}\text { http://biotools.umassmed.edu/bioapps/primer } \\
\underline{\text { 3 www.cgi }}\end{array}$ \\
\hline Primer3Plus & http://www.bioinformatics.nl/cgi- \\
\hline
\end{tabular}




\begin{tabular}{|c|c|}
\hline & bin/primer3plus/primer3plus.cgi \\
\hline Primer-BLAST & $\begin{array}{l}\text { http://www.ncbi.nlm.nih.gov/tools/primer- } \\
\text { blast/index.cgi?LINK LOC=NcbiHomeAd }\end{array}$ \\
\hline GeneFisher2 & $\begin{array}{l}\text { http://bibiserv.techfak.uni- } \\
\text { bielefeld.de/genefisher2/ }\end{array}$ \\
\hline $\begin{array}{l}\text { IDT OligoAnalyzer } \\
3.1\end{array}$ & $\begin{array}{l}\text { http://eu.idtdna.com/analyzer/applications/ol } \\
\text { igoanalyzer/ }\end{array}$ \\
\hline \multicolumn{2}{|c|}{ 5. DNA and Protein Sequence Similarity Searches } \\
\hline NCBI BLAST & http://blast.ncbi.nlm.nih.gov/Blast.cgi \\
\hline $\begin{array}{l}\text { Advanced BLAST } \\
\text { (EMBnet-CH/SIB }\end{array}$ & $\begin{array}{l}\text { http://www.ch.embnet.org/software/aBLAS } \\
\text { T.html }\end{array}$ \\
\hline $\begin{array}{l}\text { WU-BLAST } \\
\text { (EMBL-EBI) }\end{array}$ & http://www.ebi.ac.uk/Tools/sss/wublast/ \\
\hline \multicolumn{2}{|c|}{ 6. DNA and Protein Sequence Alignment } \\
\hline ClustalW2 & http://www.ebi.ac.uk/Tools/msa/clustalw2/ \\
\hline ALIGN & http://xylian.igh.cnrs.fr/bin/align-guess.cgi \\
\hline LALIGN & $\begin{array}{l}\text { http://www.ch.embnet.org/software/LALIG } \\
\text { N_form.html }\end{array}$ \\
\hline T- Coffee & http://tcoffee.crg.cat/apps/tcoffee/index.html \\
\hline \multicolumn{2}{|l|}{ 7. Phylogeny } \\
\hline ClustalW2 & $\begin{array}{l}\text { http://www.ebi.ac.uk/Tools/phylogeny/clusta } \\
\text { lw2_phylogeny/ }\end{array}$ \\
\hline Phylip & $\begin{array}{l}\text { http://bioweb2.pasteur.fr/phylogeny/intro- } \\
\text { en.html }\end{array}$ \\
\hline Phylogeny.fr & $\begin{array}{l}\text { http://www.phylogeny.fr/version2_cgi/index } \\
\text {.cgi }\end{array}$ \\
\hline PhyML 3.0 & http://atgc.lirmm.fr/phyml/ \\
\hline TreeTop & $\begin{array}{l}\text { http://www.genebee.msu.su/services/phtree } \\
\text { reduced.html }\end{array}$ \\
\hline BIONJ & $\begin{array}{l}\text { http://mobyle.pasteur.fr/cgi- } \\
\text { bin/portal.py?\#forms::bionj }\end{array}$ \\
\hline \multicolumn{2}{|c|}{$\begin{array}{l}\text { 8. Protein Chemistry (Amino acid composition/pI/Mass/ } \\
\text { Extinction coefficient/ Hydrophilicity) }\end{array}$} \\
\hline $\begin{array}{l}\text { PROTEIN } \\
\text { CALCULATOR v3.3 }\end{array}$ & $\begin{array}{l}\text { http://www.scripps.edu/ cdputnam/protcalc. } \\
\text { html }\end{array}$ \\
\hline PASy) & http://au.expasy.org/tools/pi tool.html \\
\hline $\begin{array}{l}\text { Compute pI/Mw tool } \\
\text { (ExPasy) }\end{array}$ & http://au.expasy.org/tools/pi_tool.html \\
\hline Biochemistry-online & $\begin{array}{l}\text { http://vitalonic.narod.ru/biochem/index_en.h } \\
\text { tml }\end{array}$ \\
\hline $\begin{array}{l}\text { Peptide Property } \\
\text { Calculator } \\
\text { (GenScript) }\end{array}$ & $\begin{array}{l}\text { https://www.genscript.com/ssl- } \\
\text { bin/site2/peptide_calculation.cgi }\end{array}$ \\
\hline \multicolumn{2}{|c|}{ 9. Protein Secondary Structure Prediction } \\
\hline $\begin{array}{l}\text { NPS@ Secondary } \\
\text { structure prediction }\end{array}$ & $\begin{array}{l}\text { http://npsa-pbil.ibcp.fr/cgi- } \\
\text { bin/npsa automat.pl?page=npsa sspred.html }\end{array}$ \\
\hline PSIPRED & http://bioinf.cs.ucl.ac.uk/psipred/ \\
\hline YASPIN & http://www.ibi.vu.nl/programs/yaspinwww/ \\
\hline Jpred3 & $\begin{array}{l}\text { http://www.compbio.dundee.ac.uk/www- } \\
\text { jpred/ }\end{array}$ \\
\hline \multicolumn{2}{|c|}{ 10. Motif/ Domain Searches } \\
\hline Motif Scan & http://myhits.isb-sib.ch/cgi-bin/motif_scan \\
\hline Motif Search & http://motif.genome.jp/ \\
\hline $\begin{array}{l}\text { ScanProsite } \\
\text { (ExPASy) }\end{array}$ & http://expasy.org/tools/scanprosite/ \\
\hline $\begin{array}{l}\text { InterProScan (EMBL- } \\
\text { EBI) }\end{array}$ & http://www.ebi.ac.uk/Tools/pfa/iprscan/ \\
\hline CDD (NCBI) & $\begin{array}{l}\text { http://www.ncbi.nlm.nih.gov/Structure/cdd/c } \\
\text { dd.shtml }\end{array}$ \\
\hline Pfam & http://pfam.sanger.ac.uk/search \\
\hline \multicolumn{2}{|c|}{ 11. Protein Tertiary Structure Prediction } \\
\hline SWISS-MODEL & http://swissmodel.expasy.org/ \\
\hline I- TASSER & $\begin{array}{l}\text { http://zhanglab.ccmb.med.umich.edu/I- } \\
\text { TASSER/ }\end{array}$ \\
\hline CPHmodels & http://www.cbs.dtu.dk/services/CPHmodels/ \\
\hline ESyPred3D & $\begin{array}{l}\text { http://www.fundp.ac.be/sciences/biologie/ur } \\
\text { bm/bioinfo/esypred// }\end{array}$ \\
\hline \multicolumn{2}{|c|}{ 12. Protein Tertiary Structure Validation } \\
\hline $\begin{array}{l}\text { SAVES (NIH MBI } \\
\text { Laboratory) }\end{array}$ & http://nihserver.mbi.ucla.edu/SAVES/ \\
\hline JCSG Structural & http://www.jcsg.org/scripts/pr \\
\hline
\end{tabular}

\begin{tabular}{|c|c|}
\hline Validation Central & cgi \\
\hline VADAR & $\begin{array}{l}\text { http://redpoll.pharmacy.ualberta.ca/vadar/ind } \\
\text { ex.html }\end{array}$ \\
\hline WHAT IF & $\begin{array}{l}\text { http://swift.cmbi.ru.nl/servers/html/index.ht } \\
\text { ml }\end{array}$ \\
\hline Qmean (EsPASy) & $\begin{array}{l}\text { http://swissmodel.expasy.org/qmean/cgi/inde } \\
\text { x.cgi }\end{array}$ \\
\hline RAMPAGE & $\begin{array}{l}\text { http://mordred.bioc.cam.ac.uk/ rapper/ramp } \\
\text { age.php }\end{array}$ \\
\hline \multicolumn{2}{|c|}{ 13. Ligand Binding Site /Protein Pocket Prediction } \\
\hline Q-SiteFinder & $\begin{array}{l}\text { http://www.modelling.leeds.ac.uk/qsitefinder } \\
\underline{\underline{L}}\end{array}$ \\
\hline 3DligandSite & http://www.sbg.bio.ic.ac.uk/ 3dligandsite/ \\
\hline LIGSITE & http://projects.biotec.tu-dresden.de/pocket/ \\
\hline Pocket- Finder & $\begin{array}{l}\text { http://www.bioinformatics.leeds.ac.uk/pocke } \\
\text { tfinder }\end{array}$ \\
\hline CASTp & http://sts.bioengr.uic.edu/castp/ \\
\hline \multicolumn{2}{|c|}{ 14. Active site Prediction } \\
\hline PAR-3D & $\begin{array}{l}\text { http://sunserver.cdfd.org.in:8080/protease/P } \\
\text { AR 3D/index.html }\end{array}$ \\
\hline \multicolumn{2}{|c|}{ 15. Signal Peptide Cleavage Site Prediction } \\
\hline SignalP 3.0 Server & http://www.cbs.dtu.dk/services/SignalP/ \\
\hline \multicolumn{2}{|c|}{ 16. Protein Stability Changes Prediction for Single-Site Mutations } \\
\hline Mupro & $\underline{\underline{\mathrm{http}} / / / \text { www.ics.uci.edu/ baldig/mutation.htm }}$ \\
\hline I-Mutant2.0 & $\begin{array}{l}\text { http://gpcr2.biocomp.unibo.it/cgi/predictors/ } \\
\text { I-Mutant2.0/I-Mutant2.0.cgi }\end{array}$ \\
\hline \multicolumn{2}{|c|}{$\begin{array}{l}\text { 17. Prediction of Atomic Interactions in Protein Tertiary } \\
\text { Structure }\end{array}$} \\
\hline $\begin{array}{l}\text { PIC (Protein } \\
\text { Interaction calculator) }\end{array}$ & http://crick.mbu.iisc.ernet.in/ PIC/ \\
\hline
\end{tabular}

Table 4 List of Bioinformatics software available for download

\begin{tabular}{|c|c|c|}
\hline Software & Application & Download site \\
\hline $\begin{array}{l}\text { CLC } \\
\text { Sequence } \\
\text { Viewer }\end{array}$ & $\begin{array}{l}\text { - To make a large number of } \\
\text { bioinformatics analyses (e.g. } \\
\text { translation, reverse } \\
\text { translation, restriction sites } \\
\text { searches, sequence } \\
\text { alignment, creates } \\
\text { phylogenetic tree, sequence } \\
\text { shuffling) }\end{array}$ & $\begin{array}{l}\text { http://www.clcbio.com/ind } \\
\text { ex.php?id=28 }\end{array}$ \\
\hline Bioedit & $\begin{array}{l}\text { - Sequence alignment } \\
\text { - Sequence analysis }\end{array}$ & $\begin{array}{l}\text { http://www.mbio.ncsu.edu } \\
\text { /bioedit/bioedit.html }\end{array}$ \\
\hline Mega4 & $\begin{array}{l}\text { - Sequence alignment } \\
\text { - Infers phylogenetic tree } \\
\text { - Infers ancestral sequences } \\
\text { - Web- based databases } \\
\text { mining } \\
\text { - Estimates rate of } \\
\text { evolutionary } \\
\text { - Tests evolutionary } \\
\text { hypotheses }\end{array}$ & $\begin{array}{l}\text { http://www.megasoftware. } \\
\text { net/mega4/index.html }\end{array}$ \\
\hline Pymol & $\begin{array}{l}\text { - To visualize and analyse } \\
\text { macromolecular structure }\end{array}$ & http://www.pymol.org/ \\
\hline $\begin{array}{l}\text { YASARA } \\
\text { View }\end{array}$ & $\begin{array}{l}\text { - To visualize and analyse } \\
\text { macromolecular structure }\end{array}$ & $\begin{array}{l}\text { http://www.yasara.org/ind } \\
\text { ex.html }\end{array}$ \\
\hline $\begin{array}{l}\text { Swiss- } \\
\text { PDB } \\
\text { Viewer }\end{array}$ & $\begin{array}{l}\text { - To visualize and analyse } \\
\text { protein structure } \\
\text { - Structure superimposition } \\
\text { - Amino acid mutations } \\
\end{array}$ & http://spdbv.vital-it.ch/ \\
\hline VMD & $\begin{array}{l}\text { - To visualize large } \\
\text { biomolecular system }\end{array}$ & $\begin{array}{l}\text { http://www.ks.uiuc.edu/Re } \\
\text { search/vmd/ }\end{array}$ \\
\hline Autodock & $\begin{array}{l}\text { - To predict the binding of } \\
\text { small molecule/ ligand to a } \\
\text { receptor of known 3D } \\
\text { structure }\end{array}$ & $\begin{array}{l}\text { http://autodock.scripps.edu } \\
\underline{I}\end{array}$ \\
\hline $\begin{array}{l}\text { Autodock } \\
\text { Vina }\end{array}$ & $\begin{array}{l}\text { - Drug discovery, molecular } \\
\text { docking and virtual screening }\end{array}$ & http://vina.scripps.edu/ \\
\hline
\end{tabular}




\subsection{TRENDS AND PROGRESS OF PROTEIN ENGINEERING IN SOUTHEAST ASIA}

Biotechnology development in Southeast Asia has gained much interest from the world in the recent years. Lately, an article entitled "Biotechnology in Southeast Asia: current capabilities, future opportunities", written by Cecil Brown et al., was published in the International Focus [28]. It was mentioned in the article that "It is clear that as Western biotech players offshore pieces of their value chain, Southeast Asia will play an increasingly important role". Unfortunately, Malaysia was not discussed in the report despite the efforts put in by the Malaysian government to increase the numbers and quality of biotechnology researches for the past five years.

The following summary is not able to cover all of the protein engineering researches in the Southeast Asia but some trends and successful projects are identified to give an overview of such work done in this region. Table 5 shows a search result in the ISI Web of Knowledge database. The figures shown are not meant to list an accurate statistical data since not all reports are maintained by the database. The keywords used in this search were "site directed mutagenesis" and "directed evolution".

At the time of writing this report, Singapore has the highest publication numbers among the countries in Southeast Asia, followed by Thailand. Japan and China (not in Southeast Asia), both have 1090 and 3178 reports on protein engineering, respectively. By comparison, Malaysia is, far behind in research related to the protein-engineering field.

In Malaysia, protein-engineering experts are scarce. To the best of the authors' knowledge, there are two main researchers from the Biomip Research Group (Biotechnology Research Alliance, Universiti Teknologi Malaysia, UTM) who are actively involved in protein engineering researches, with focus on carbohydrate degradation enzymes. They have several publications and pending patent files. There are also a few new researchers who are initiating projects related to protein modifications in dehalogenase and protein for biosensor. The Universiti Putra Malaysia (UPM) has an excellent and strong team of researchers working on lipase, protease and PHA synthase, while the Universiti Kebangsaan Malaysia (UKM) and Malaysia Genome Institute (MGI) teams are working on protease, antibodies and cutinase research while a researcher from the International Medical University (IMU) is looking at the functional characteristic of cytochrome. In addition, one of the researchers in International Islamic University Malaysia (IIUM) is active in the study of mutations effect on mosquitocidal toxin Cry4Ba against Aedes aegypti. Table 6 lists some of the outstanding works previously done in Malaysia and other Southeast Asia countries related to protein engineering.

Table 5 Search result in the ISI Web of Knowledge database from the use of keywords related to protein engineering. (* are not Southeast Asia countries)

\begin{tabular}{ccc}
\hline Countries & $\begin{array}{c}\text { Site directed } \\
\text { mutagenesis }\end{array}$ & Directed evolution \\
\hline Malaysia & 11 & 3 \\
Singapore & 130 & 14 \\
Thailand & 52 & 3 \\
Indonesia & 7 & 0 \\
Philippines & 2 & 3 \\
China* & 949 & 141 \\
Japan* & 2969 & 209 \\
\hline
\end{tabular}

Table 6 Selected researches on protein engineering in Southeast Asia

\begin{tabular}{|c|c|c|c|c|c|c|}
\hline & Protein & Source & Aims & Approach & Research outcomes & Ref \\
\hline \multirow{5}{*}{ 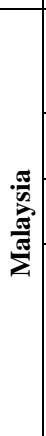 } & \multirow{2}{*}{ CGTase } & Bacillus G1 & Activity & SDM & $\gamma$-CD production increased from 10 to $39 \%$ & [29] \\
\hline & & Bacillus G1 & $\begin{array}{l}\text { Protein } \\
\text { secretion }\end{array}$ & ePCR & Secretion of CGTase increased by $35-217 \%$ & {$[30]$} \\
\hline & Cry19Aa & $\begin{array}{l}\text { Bacillus } \\
\text { thuringiensis }\end{array}$ & Toxicity & SDM & Aedes toxicity increased by 42,000 fold & {$[31]$} \\
\hline & Cutinase & $\begin{array}{l}\text { Glomerella } \\
\text { cingulata }\end{array}$ & $\begin{array}{l}\text { Structural } \\
\text { studies }\end{array}$ & SDM & $\begin{array}{l}\text { H204N mutant was catalytically inactive, indicating the } \\
\text { importance in enzyme mechanism }\end{array}$ & [32] \\
\hline & $\begin{array}{l}\text { Glycerol } \\
\text { dehydrogenase }\end{array}$ & $\begin{array}{l}\text { E. coli } \mathrm{K}-12, \\
\text { Salmonella } \\
\text { enterica, and } \\
\text { Klebsiella } \\
\text { pneumoniae } \\
\text { MGH78578 }\end{array}$ & Activity & $\begin{array}{l}\text { DNA } \\
\text { Shuffling+ } \\
\text { SDM }\end{array}$ & $\begin{array}{l}2.6 \text { fold increase in activity } \\
\text { Consolidation of DNA shuffling and D121A causes } 26 \text { fold } \\
\text { increase in activity }\end{array}$ & [33] \\
\hline \multirow{5}{*}{ 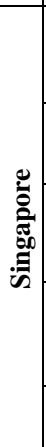 } & $\begin{array}{l}\text { Glutathione } \\
\text { transferase }\end{array}$ & Anopheles dirus & $\begin{array}{l}\text { Structural } \\
\text { studies }\end{array}$ & SDM & $\begin{array}{l}\text { Tyr111 indirectly stabilizes GSH binding, Tyr119 modulates } \\
\text { hydrophobic substrate binding and Phe123 indirectly modulates } \\
\text { catalysis }\end{array}$ & [34] \\
\hline & $\begin{array}{l}\text { Flavonol } \\
\text { synthase }\end{array}$ & $\begin{array}{l}\text { Arabidopsis } \\
\text { thaliana }\end{array}$ & $\begin{array}{l}\text { Structural } \\
\text { studies }\end{array}$ & SDM & $\begin{array}{l}\text { Mutations at H221, D223, H277 and R287 completely } \\
\text { abolished enzymes activities }\end{array}$ & [35] \\
\hline & $\begin{array}{l}\text { Gentisate } 1,2- \\
\text { dioxygenase }\end{array}$ & $\begin{array}{l}\text { Pseudomonas } \\
\text { alcaligenes }\end{array}$ & Activity & SDM & $\begin{array}{l}\text { Y181F, demonstrated 4-, 3-, 6-, and 16-fold increases in relative } \\
\text { activity towards gentisate and 3-fluoro-, 4-methyl-, and 3- } \\
\text { methylgentisate, respectively }\end{array}$ & [36] \\
\hline & Lactonase & $\begin{array}{l}\text { Geobacillus } \\
\text { kaustophilus } \\
\text { HTA426 }\end{array}$ & Activity & $\begin{array}{l}\text { Directed } \\
\text { evolution }\end{array}$ & $\begin{array}{l}\text { E101N/R230I mutant had an increased value of } k(\mathrm{cat}) / \mathrm{K}(\mathrm{m}) \text { of } \\
\text { 72-fold toward 3-oxo-N-dodecanoyl-L-homoserine lactone }\end{array}$ & {$[10]$} \\
\hline & $\begin{array}{l}\text { Pyranose 2- } \\
\text { oxidase }\end{array}$ & A. niger & Activity & Semi-SDM & Catalytic constant increased 5.7 fold & [37] \\
\hline
\end{tabular}




\begin{tabular}{|l|l|l|l|l|l|l|}
\hline $\begin{array}{l}\text { D-Aspartate } \\
\text { oxidase }\end{array}$ & Mouse & $\begin{array}{l}\text { Structural } \\
\text { studies }\end{array}$ & SDM & $\begin{array}{l}\text { Arg-216 is important for the catalytic activity and substrate } \\
\text { specificity whereas Arg-237 is important for catalytic activity } \\
\text { and substrate recognition }\end{array}$ \\
\hline [38] \\
Laccase & $\begin{array}{l}\text { Pseudomonas } \\
\text { aeruginosa } \\
\text { Azurin }\end{array}$ & Activity & SDM & $\begin{array}{l}\text { The activities of both CueO and Delta alpha 5-7 CueO were } \\
\text { also enhanced by mutations to break down the hydrogen bond } \\
\text { between the imidazole group of His443 and the beta-carboxy } \\
\text { group of Asp439 }\end{array}$ & $\begin{array}{l}\text { G117E exhibited lower activity in the hydrolysis of N-[3-(2- } \\
\text { furyl)acryloyl]-glycyl-L-leucine amide and higher activity in } \\
\text { the hydrolysis of N-carbobenzoxy-L-aspartyl-L-phenylalanine } \\
\text { methyl ester than the wild-type thermolysin. G117K and } \\
\text { G117R exhibited considerably reduced activities. }\end{array}$ \\
\hline [40]
\end{tabular}

\section{References}

[1] Zhang, J., Chiodini, R., Badr, A., and Zhang, G. 2011. The Impact of Next-generation Sequencing on Genomics. Journal of Genetics and Genomics. 38(3): 95-109.

[2] Benetti, F., and Legname, G. 2009. De Novo Mammalian Prion Synthesis. Prion. 3(4): 213-219.

[3] Declerck, N., Machius, M., Wiegand, G., Huber, R., and Gaillardin, C. 2000. Probing Structural Determinants Specifying High Thermostability in Bacillus Licheniformis $\alpha$-amylase. Journal of Molecular Biology. 301(4): 1041-1057.

[4] Lin, K. F., Lee, T. R., Tsai, P. H., Hsu, M. P., Chen, C. S., and Lyu, P. C. 2007. Structure-based Protein Engineering for $\alpha$-amylase Inhibitory Activity of Plant Defensin. Proteins: Structure, Function, and Bioinformatics. 68(2): 530-554.

[5] Glieder, A., Farinas, E. T. and Arnold, F. H. 2002. Laboratory Evolution of a Soluble Self- Sufficient, Highly Active Alkane Hydroxylase. Nature Biotechnology. 20: 1135-1139.

[6] Wang, Q., Buckle, A. M., Foster, N. M., Johnson, C. M. and Fersht, A. R. 1999. Design of Highly Stable Functional GroEL Minichaperones. Protein Science. 8: 2186-2193.

[7] Yan, Z. X., Hui, R., Lin, M., Qing, H. G., Jun, T. X. and He, C. Q. 2006. Enhancement of the Thermostability of $\beta$ - 1,3-1,4-glucanase by Directed Evolution. Journal of Zhejiang Universiti SCIENCE A. 7(11): 1948-1955

[8] Parsiegla, G., Schmidt, A. K. and Schulz, G. E. 1998. Substrate Binding to a Cyclodextrin Glycosyltransferase and Mutations Increasing the $\gamma$-cyclodextrin Production. European Journal of Biochemistry. 255: 710-717.

[9] Brange, J., Ribel, U., Hansen, J. F., Dodson, G., Hansen, M. T., Havelund, S., Melberg, S. G., Norris, F., Norris, K., Snel, L., Sorensen, A. R. and Voigt, H. O. 1988. Monomeric insulins obtained by protein engineering and their medical implications. Nature, 333:679-682.

[10] Chow, J. Y., Xue, B., Lee, K. H., Tung, A., Wu, L., Robinson, R. C., and Yew, W. S. 2010. Directed Evolution of a Thermostable QuorumQuenching Lactonase from the Amidohydrolase Superfamily. Journal of Biological Chemistry. 285(52): 40911-40920.

[11] Zhou, M., Xu, H., Wei, X., Ye, Z., Wei, Y., Gong, W., Wang, Y. and Zhu, Z. 2006. Identification of a Glyphosate-Resistant Mutant of Rice 5-Enolpyruvylshikimate-3-Phosphate Synthase Using a Directed Evolution Strategy. Plant Physiology. 140: 184-195.

[12] Castle, L. A., Siehl, D. L., Gorton, R., Patten, P. A., Chen, Y. H., Bertain, S., Choe, H. J., Duck, N., Wong, J., Liu, D., and Lassner, M. W. 2004. Discovery and Directed Evolution of a Glyphosate Tolerance Gene. Science. 304: 1151-1154.

[13] Handa, P. and Varshney, U. 1998. Rapid and Reliable Site Directed Mutagenesis Using Kunkel's Approach. Indian Journal of Biochemistry and Biophysics. 25(2): 63-66.

[14] Kammann, M., Laufs, J., Schell, J. and Gronenbom, B. 1989. Rapid Insertional Mutagenesis of DNA by Polymerase Chain Reaction (PCR). Nucleic Acids Research. 17: 5404.

[15] Ke, S. H. and Madison, E. L. 1997. Rapid and Efficient Site-directed Mutagenesis by Single-tube 'Megaprimer' PCR Method. Nucleic Acids Research. 25(16): 3371-3372.
[16] McPherson, M. and Moller, S. 2006. PCR. $2^{\text {nd }}$ ed. United Kingdom: Taylor \& Francis Group.

[17] Howorka, S. and Bayley, H. 2002. High-Throughput Scanning Mutagenesis by recombinant Polymerase Chain Reaction. In Braman, J. (Ed.) Methods in Molecular Biology: In Vitro Mutagenesis Protocols). New Jersey: Humana Press Inc. 139-147

[18] Khemakhem, B., Ali, M. B., Aghajari, N., Juy, M., Haser, R., and Bejar, S. 2009. The Importance of an Extra Loop in the B-Domain of an A-Amylase from B. stearothermophilus US100. Biochemical and Biophysical Research Communications. 385(1): 78-83.

[19] Witkowski, W. A., and Hardy, J. A. 2009. L2' Loop is Critical for Caspase-7 Active Site Formation. Protein Science. 18(7): 1459-1468.

[20] Rezaie, A. R., and Yang, L. 2005. Deletion of the 60-loop Provides New Insights into the Substrate and Inhibitor Specificity of Thrombin. Thrombosis and Haemostasis. 93: 1047-1054.

[21] Santini, S., and Derreumaux, P. 2004. Helix H1 of the Prion Protein is Rather Stable Against Environmental Perturbations: Molecular Dynamics of Mutation and Deletion Variants of PrP(90-231). Cellular and Molecular Life Sciences. 61(7): 951-960.

[22] Babu, K. S., Antony, A., Muthukumaran, T., and Meenakshisundaram, S. 2008. Construction of Intein-Mediated Hgmcsf Expression Vector and its Purification in Pichia Pastoris. Protein Expression and Purification. 57(2): 201-205.

[23] Gruber, K., Klintschar, G., Hayn, M., Schlacher, A., Steiner, W. and Kratky, C. 1998. Thermophilic xylanase from Thermomyces lanuginosus: High Resolution X-ray Structure and Modelling Study. Biochemistry. 37: 13475-13485.

[24] Brakmann, S. and Schwienhorst, A. 2004. Evolutionary Methods in Biotechnology. Wiley-VCH, Weinheim.

[25] Volkov, A. A. and Arnold, F. H. 2000. Methods for in vitro DNA Recombination and Random Chimeragenesis. Methods in Enzymology. 328: 447-456.

[26] Eswar, N., Marti-Renom, M. A., Webb, B., Madhusudhan, M. S., Eramian, D., Shen, M., Pieper, U. and Sali, A. 2006. Comparative Protein Structure Modeling with MODELLER. Current Protocols in Bioinformatics. (15:5.6.1-5.6.30.). California: John Wiley \& Sons, Inc.

[27] Zhang, Y. 2008. I-TASSER Server for Protein 3D Structure Prediction. BMC Bioinformatics. 38(3): 95-109.

[28] Brown, C., George, G., Jasaroska, S., Kidolezi, Y. and Ochoa, J. http://www.kellogg.northwestern.edu/Departments/International/Intern ationalFocus/Article/2011_Southeast\%20Asian\%20Biotech.aspx.

[29] Goh, K. M., Mahadi, N. M., Hassan, O., Rahman, R. N. Z. R. A., and Illias, R. M. 2009. A Predominant $\beta$-CGTase G1 Engineered to Elucidate the Relationship between Protein Structure and Product specificity. Journal of Molecular Catalysis B: Enzymatic. 57(1-4): 270-277.

[30] Low, K. O., Mahadi, N. M., Rahim, R. A., Rabu, A., Bakar, F. D. A., Murad, A. M. A. and Illias, R. M. 2010. Enhanced Secretory Production of Hemolysin-mediated Cyclodextrin Glucanotransferase in Escherichia Coli by Random Mutagenesis of the ABC Transporter System. Journal of Biotechnology. 150: 453-459.

[31] Abdullah, M. A. F., and Dean, D. H. 2004. Enhancement of Cry19Aa Mosquitocidal Activity Against Aedes Aegypti by Mutations in the 
Putative Loop Regions of Domain II. Applied Environmental Microbiology. 70(6): 3769-3771.

[32] Nyon, M. P., Rice, D. W., Berrisford, J. M., Hounslow, A. M., Moir, A. J. G., Huang, H., Nathan, S., Mahadi, N. M., Bakar, F. D., and Craven, C. J. 2009. Catalysis by Glomerella cingulata Cutinase Requires Conformational Cycling Between the Active and Inactive States of its Catalytic Triad. Journal of Molecular Biology. 385(1): 226-235.

[33] Zhang, H., Lountos, G., Ching, C., and Jiang, R. 2010. Engineering of Glycerol Dehydrogenase for Improved Activity Towards 1, 3butanediol. Applied Microbiology and Biotechnology. 88(1): 117-124.

[34] Wongsantichon, J., Robinson, Robert, C., and Ketterman, and Albert, J. 2010. Structural Contributions of Delta Class Glutathione Transferase Active-site Residues to Catalysis. Biochemical Journal. 428: 25-32.

[35] Chua, C. S., Biermann, D., Goo, K. S., and Sim, T. S. 2008 Elucidation of Active Site Residues of Arabidopsis Thaliana Flavonol Synthase Provides a Molecular Platform for Engineering Flavonols. Phytochemistry. 69(1): 66-75.

[36] Tan, C. L., Yeo, C. C., Khoo, H. E., and Poh, C. L. 2005. Replacement of Tyrosine 181 by Phenylalanine in Gentisate 1,2-Dioxygenase I from Pseudomonas alcaligenes NCIMB 9867 Enhances Catalytic Activities. Journal of Bacteriology. 187(21): 7543-7545.

[37] Spadiut, O., Pisanelli, I., Maischberger, T., Peterbauer, C., Gorton, L. Chaiyen, P., and Haltrich, D. 2009. Engineering of pyranose 2-oxidase: Improvement for Biofuel Cell and Food Applications through SemiRational Protein Design. Journal of Biotechnology. 139(3): 250-257.
[38] Katane, M., Saitoh, Y., Maeda, K., Hanai, T., Sekine, M., Furuchi, T., and Homma, H. 2011. Role of the Active Site Residues Arginine-216 And Arginine-237 in the Substrate Specificity of Mammalian DAspartate Oxidase. Amino Acids. 40(2): 467-476.

[39] Kataoka, K., Hirota, S., Maeda, Y., Kogi, H., Shinohara, N., Sekimoto, M., and Sakurai, T. 2011. Enhancement of Laccase Activity through the Construction and Breakdown of a Hydrogen Bond at The Type I Copper Center in Escherichia coli $\mathrm{CueO}$ and the Deletion Mutant $\Delta \alpha 5$ 7 CueO. Biochemistry. 50(4): 558-565.

[40] Menach, E., Yasukawa, K., and Inouye, K. 2010. Effects of SiteDirected Mutagenesis of the Loop Residue of the N-Terminal Domain Gly117 of Thermolysin on its Catalytic Activity. Bioscience, Biotechnology, and Biochemistry. 74: 2457-2462.

[41] Yasukawa, K., Mizuno, M., Konishi, A., and Inouye, K. 2010. Increase in Thermal Stability of Moloney Murine Leukaemia Virus Reverse Transcriptase by Site-directed Mutagenesis. Journal of Biotechnology. 150(3): 299-306.

[42] Suzuki, Y., Asada, K., Miyazaki, J., Tomita, T., Kuzuyama, T., and Nishiyama, M. 2010. Enhancement of the Latent 3-isopropylmalate Dehydrogenase Activity of Promiscuous Homoisocitrate Dehydrogenase by Directed Evolution. Biochemical Journal. 431: 401-410.

[43] Kawata, T., and Ogino, H. 2010. Amino Acid Residues Involved in Organic Solvent-stability of the LST-03 Lipase. Biochemical and Biophysical Research Communications. 400(3): 384-388. 